\title{
Selected vitamins and trace elements support immune function by strengthening epithelial barriers and cellular and humoral immune responses
}

\author{
Silvia Maggini ${ }^{1}{ }^{*}$, Eva S. Wintergerst ${ }^{2}$, Stephen Beveridge ${ }^{1}$ and Dietrich H. Hornig ${ }^{3}$ \\ ${ }^{1}$ Bayer Consumer Care Ltd, Peter Merian-Strasse 84, P.O. Box, 4002 Basel \\ ${ }^{2}$ Bayer Diabetes Care Ltd, Peter Merian-Strasse 84, P.O. Box, 4002 Basel and ${ }^{3}$ Reinach, Switzerland
}

Adequate intakes of micronutrients are required for the immune system to function efficiently. Micronutrient deficiency suppresses immunity by affecting innate, $\mathrm{T}$ cell mediated and adaptive antibody responses, leading to dysregulation of the balanced host response. This situation increases susceptibility to infections, with increased morbidity and mortality. In turn, infections aggravate micronutrient deficiencies by reducing nutrient intake, increasing losses, and interfering with utilization by altering metabolic pathways. Insufficient intake of micronutrients occurs in people with eating disorders, in smokers (active and passive), in individuals with chronic alcohol abuse, in certain diseases, during pregnancy and lactation, and in the elderly. This paper summarises the roles of selected vitamins and trace elements in immune function. Micronutrients contribute to the body's natural defences on three levels by supporting physical barriers (skin/mucosa), cellular immunity and antibody production. Vitamins A, $\mathrm{C}, \mathrm{E}$ and the trace element zinc assist in enhancing the skin barrier function. The vitamins $\mathrm{A}, \mathrm{B}_{6}, \mathrm{~B}_{12}, \mathrm{C}, \mathrm{D}, \mathrm{E}$ and folic acid and the trace elements iron, zinc, copper and selenium work in synergy to support the protective activities of the immune cells. Finally, all these micronutrients, with the exception of vitamin $\mathrm{C}$ and iron, are essential for antibody production. Overall, inadequate intake and status of these vitamins and trace elements may lead to suppressed immunity, which predisposes to infections and aggravates malnutrition. Therefore, supplementation with these selected micronutrients can support the body's natural defence system by enhancing all three levels of immunity.

Vitamins B $_{6}$ : Folate: B $_{12}$ : C: A: D: E: Trace elements Selenium: Zinc: Copper: Iron; Effects on immune response: Nutrient deficiency: Supplementation

Excellent reviews on the immune system are available ${ }^{1-4}$. The immune system is an intricate network of specialized tissues, organs, cells, and chemicals protecting the host from infectious agents and other noxious insults. The immune response to invaders can be divided into two interactive systems: innate and adaptive immunity. Innate immunity is present at birth and provides the first barrier against "invaders" consisting of e.g. skin, mucus secretions, and the acidity of the stomach. Adaptive immunity is the second barrier to infection and is acquired later in life, such as after an immunization or successfully fighting off an infection. It retains a memory of all the invaders it has faced and this accelerates antibody production. Although defence mechanisms of innate and adaptive immunity are very complex, they can be described as being organized in three main clusters: physical barriers (e.g. skin, mucosa, mucus secretions), immune cells and antibodies. Inter-individual variations in many immune functions exist within the normal healthy population and are due to genetics, age, gender, smoking habits, habitual levels of exercise, alcohol consumption, diet, stage in the female menstrual cycle, stress, etc ${ }^{5}$. Nutrient status is an important factor contributing to immunocompetence and the profound interactions among nutrition, infection, and health have been recognised ${ }^{6,7}$. In the recent decade, substantial research has focused on the role of nutrition and especially on the contribution of the role of micronutrients to an optimum functioning of the immune system. The objective of this overview is to demonstrate that selected micronutrients work in synergy and support the different components of the immune system such as physical barriers, cellular response and antibody production. An inadequate or deficient micronutrient status negatively influences the body's defences and thus impairs the body's overall ability to combat infections (Table 1).

\section{Vitamins and immune function}

\section{Vitamin A}

Vitamin A, acting via all-trans retinoic acid, 9-cis retinoic acid, or other metabolites and nuclear retinoic acid receptors, plays an important role in the regulation of innate and cellmediated immunity and humoral antibody response $\mathrm{e}^{8,9}$. In vitamin A deficiency the integrity of mucosal epithelium is altered. As a consequence, an increased susceptibility to various pathogens in the eye, and in the respiratory and gastrointestinal tracts is observed. Vitamin A deficient children have an increased risk of developing respiratory disease ${ }^{10}$, and increased severity of diarrhoeal disease ${ }^{11}$. The benefits of vitamin A supplementation in reducing the morbidity and mortality from acute measles in infants and children, diarrhoeal diseases in pre-school children in developing countries, acute respiratory infections, malaria, tuberculosis, and infections in pregnant and lactating women have been reviewed $^{12-14}$. 
Table 1. Summary of the sites of action of micronutrients on the immune system

\begin{tabular}{lll}
\hline Epithelial barriers & Cellular immunity & Antibody production \\
\hline Vitamin $\mathrm{A}$ & Vitamin $\mathrm{A}$ & Vitamin $\mathrm{A}$ \\
Vitamin $\mathrm{C}$ & ${\text { Vitamin } \mathrm{B}_{6}}$ & Vitamin $\mathrm{B}_{6}$ \\
Vitamin E & Vitamin $\mathrm{B}_{12}$ & Vitamin $\mathrm{B}_{12}$ \\
Zinc & Vitamin C & Vitamin D \\
& Vitamin D & Vitamin E \\
& Vitamin E & Folic acid \\
& Folic acid & Zinc \\
& Iron & Copper \\
& Zinc & Selenium \\
& Copper & \\
& Selenium & \\
\hline
\end{tabular}

Vitamin A deficiency is associated with diminished phagocytic and oxidative burst activity of macrophages activated during inflammation ${ }^{15}$, and a reduced number and activity of natural killer $(\mathrm{NK})$ cells $^{16}$. The increased production of IL12 (promoting $\mathrm{T}$ cell growth) and pro-inflammatory TNF- $\alpha$ (activating microbicidal action of macrophages) in a vitamin A deficient state may promote an excessive inflammatory response, but supplementation with vitamin A can reverse these effects ${ }^{17}$.

Lymphocyte proliferation is caused by activation of retinoic acid receptors and therefore vitamin $\mathrm{A}$ is playing an essential role in the development and differentiation of Th1 and Th2 lymphocyte subsets ${ }^{18}$. Vitamin A maintains the normal antibody mediated Th2 response by suppressing IL12 , TNF- $\alpha$, and IFN- $\gamma$ production of Th1 lymphocytes. As a consequence, in vitamin A deficiency there is an impaired ability to defend against extracellular pathogens ${ }^{19}$. Antibodymediated immunity is strongly impaired in vitamin A deficiency $^{20}$. Oral vitamin A supplementation increases delayed type hypersensitivity (DTH) in infants which may reflect vitamin A-related up-regulation of lymphocyte function $^{21}$. In humans, vitamin A supplementation has been shown to improve antibody titre response to various vaccines $^{22,23}$.

\section{Vitamin D}

Besides the effects in calcium and bone metabolism, vitamin $\mathrm{D}$ and especially its biologically active metabolite 1,25-dihydroxycholecalciferol $\left(1,25(\mathrm{OH})_{2} \mathrm{D} 3\right)$ act as powerful immunoregulators $^{24-26}$. The discovery of significant quantities of vitamin $\mathrm{D}$ receptors in monocytes, macrophages, and thymus tissue suggests a specific role of vitamin D and its metabolites in the immune system. Most cells of the immune system except B cells express vitamin D receptors ${ }^{27}$.

There is evidence from human epidemiological and animal studies that vitamin D status influences the occurrence of Th1-mediated autoimmunity diseases which is in accordance with the ability of $1,25(\mathrm{OH})_{2} \mathrm{D} 3$ to inhibit maturation of dendritic cells (DC) and down-regulate production of the immunostimulatory IL-12, and the observed increase in immunosuppressive IL-10 28,29 . Human epidemiological studies indicate supplementation with $1,25(\mathrm{OH})_{2} \mathrm{D} 3$ as an independent protective factor influencing the occurrence of Th-1 mediated autoimmunity ${ }^{30,31}$.
$1,25(\mathrm{OH})_{2} \mathrm{D} 3$ acts as an immune system modulator, preventing excessive expression of inflammatory cytokines and increasing the 'oxidative burst' potential of macrophages. Perhaps most importantly, it stimulates the expression of potent anti-microbial peptides, which exist in neutrophils, monocytes, NK cells, and in epithelial cells lining the respiratory tract where they play a major role in protecting the lung from infection $^{32}$. Volunteers inoculated with live attenuated influenza virus are more likely to develop fever and serological evidence of an immune response in the winter, a period of the year characterized by vitamin D insufficiency ${ }^{32}$. Vitamin D deficiency predisposes children to respiratory infections. Ultraviolet radiation (either from artificial sources or from sunlight) reduces the incidence of viral respiratory infections, as does cod liver oil (which contains vitamin D) ${ }^{32}$.

\section{Vitamin E}

Free radicals and lipid peroxidation are immunosuppressive and due to its strong lipid-soluble antioxidant activity vitamin $\mathrm{E}$ is able to optimise and enhance the immune response. Supplementation with vitamin $\mathrm{E}$ increases lymphocyte proliferation in response to mitogens, production of IL-2, NK cell cytotoxic activity, and phagocytic activity by alveolar macrophages, and causes an increased resistance against infectious agents indicating that higher vitamin $\mathrm{E}$ intake is promoting a Th1 cytokine mediated response and suppressing a Th2 response ${ }^{33}$.

Immune function in humans declines with age (immunosenescence). Alterations include impaired $\mathrm{T}$ cell-dependent functions such as T-cell proliferation to mitogens, antibody response after primary immunization with $\mathrm{T}$-cell dependent antigens, impaired DTH and IL-2 production, whereas IL-4 and IL- 6 are elevated. These findings could indicate a shift from a pro-inflammatory $\mathrm{Th} 1$ to a more anti-inflammatory Th2 cytokine response due to ageing ${ }^{34-36}$. Since deregulation of the responses with age is associated with a higher morbidity and mortality from infections and neoplastic diseases, vitamin $\mathrm{E}$ has been investigated in human studies with regard to its potential to improve the overall immune response, especially in the elderly ${ }^{37-46}$. Further support for a more specific role of vitamin $E$ is provided by the finding that vitamin $E$ supplementation increases IL-2 production of $\mathrm{T}$ cells and enhances a Th1 response and decreased the expression of IL-4, a stimulator of Th2 response. Other studies indicate that vitamin $\mathrm{E}$ causes a shift toward greater proportions of antigen-experienced memory $\mathrm{T}$ cells with fewer naive $\mathrm{T}$ cells ${ }^{47}$. Recent reviews comprehensively confirmed the role of vitamin $\mathrm{E}$ and immunity in man, especially in the elderly $^{4,33}$.

\section{Vitamin $C$}

Reactive oxygen species (ROS), generated by activated immune cells during the process of phagocytosis, can be scavenged by non-enzymatic antioxidants, such as vitamin $\mathrm{C}$ or by enzyme action. Whereas ROS play essential roles in intracellular killing of bacteria and other invading organisms, the immune system and other body's molecules may be vulnerable to oxidative attack. If ROS are produced in high concentrations, this fact can cause oxidative stress and lead to impaired immune response, loss of cell membrane integrity, altered membrane 
fluidity, and alteration of cell-cell communication. These alterations could contribute to degenerative disorders such as cancer and cardiovascular disease , 48,49. $^{\text {. }}$.

The immune-enhancing role of vitamin $\mathrm{C}$ has recently been reviewed $^{50}$. Vitamin $\mathrm{C}$ is highly concentrated in leukocytes and is used rapidly during infection. In fact, it has been defined as a stimulant of leukocyte functions, especially of neutrophil and monocyte movement. Vitamin $\mathrm{C}$ supplements have been shown to enhance neutrophil chemotaxis in healthy adults $(1-3 \mathrm{~g} / \mathrm{day})$ and children $(20 \mathrm{mg} / \mathrm{kg} / \mathrm{day})^{51}$. In addition, supplementation with vitamin $\mathrm{C}$ has been demonstrated to stimulate the immune system by enhancing T-lymphocyte proliferation in response to infection increasing cytokine production and synthesis of immunoglobulins ${ }^{52}$. Vitamin $\mathrm{C}$ may also play a significant role in the regulation of the inflammatory response ${ }^{53}$.

Administration of vitamin $\mathrm{C}$ results in improvement in several components of human immune response such as anti-microbicidal and NK cell activities, lymphocyte proliferation, chemotaxis, and DTH response ${ }^{54-57}$. Based on its immune-stimulating properties ${ }^{51}$, vitamin $\mathrm{C}$ was postulated to be effective in ameliorating symptoms of upper respiratory tract infections, especially the common cold. Further, plasma and leukocyte vitamin $\mathrm{C}$ concentrations fall rapidly with the onset of the infection and return to normal with the amelioration of the symptoms suggesting dosage with vitamin $\mathrm{C}$ could be beneficial for the recovery process $^{58}$. A review of the large numbers of studies on a potential effect of vitamin $\mathrm{C}$ on the common cold and respiratory infections concluded that administration of more than $1 \mathrm{~g} /$ day had no consistent effect on the incidence of common colds, but supported a moderate benefit on duration and severity of symptoms which may also be of economic advantage ${ }^{59}$.

\section{Vitamin $B_{6}$}

Vitamin $\mathrm{B}_{6}$ is essential in nucleic acid and protein biosynthesis, hence an effect on immune function is logical, since antibodies and cytokines built up from amino acids and require vitamin $B_{6}$ as coenzyme in their metabolism ${ }^{60,61}$.

Human studies demonstrate that vitamin $\mathrm{B}_{6}$ deficiency impairs lymphocyte maturation and growth, and antibody production and T-cell activity. Lymphocyte mitogenic response is impaired by dietary vitamin $\mathrm{B}_{6}$ depletion in elderly subjects and restored by administration of vitamin $B_{6}$. Effects of deficiency were seen in a decreased antibody DTH response, IL-1- $\beta$, IL-2, IL-2 receptor, NK cell activity, and in lymphocyte proliferation ${ }^{62-64}$.

Marginal vitamin $\mathrm{B}_{6}$ deficiency alters the percentage of T-helper cells and slightly decreased serum immunoglobulin $\mathrm{D}^{65}$. Marginal vitamin $\mathrm{B}_{6}$ deficiency in the elderly is associated with decreased numbers and function of circulating T-lymphocytes which can be corrected by short-term (6 weeks) supplementation with $50 \mathrm{mg}$ of vitamin $\mathrm{B}_{6} /$ day ${ }^{66}$. Decreased IL-2 production, $\mathrm{T}$ lymphocyte numbers, and $\mathrm{T}$ lymphocyte proliferation is observed in subjects undergoing vitamin $\mathrm{B}_{6}$ depletion, indicating that vitamin $\mathrm{B}_{6}$ deficiency suppresses a Th1 and promotes a Th2 cytokine mediated activity, whereas repletion reverses $\mathrm{it}^{20}$.

\section{Folate}

Folate plays a crucial role in nucleic acid and protein synthesis by supplying in concert with vitamins $\mathrm{B}_{6}$ and $\mathrm{B}_{12}$ one-carbon units, and therefore inadequate folate significantly alters the immune response. Folate deficiency modulates immune competence and resistance to infections and affects cell-mediated immunity by reducing the proportion of circulating $\mathrm{T}$ lymphocytes and their proliferation in response to mitogen activation. This effect in turn decreases resistance to infections ${ }^{67}$.

In vitro data suggest that folate status may affect the immune system by inhibiting the capacity of $\mathrm{CD}^{+} \mathrm{T}$ lymphocytes cells to proliferate in response to mitogen activation. This might explain the observation that folate deficiency enhances carcinogenesis, next to increased damage to DNA and altered methylation capacity ${ }^{68}$.

Folate supplementation of elderly individuals improves overall immune function by altering the age-associated decrease in NK cell activity supporting a Th1 response thus providing protection against infections ${ }^{69}$. Large intakes of folic acid (folate-rich diet and supplements $>400 \mu \mathrm{g} /$ day) were shown in one study to possibly impair NK cytotoxicity ${ }^{69}$, whereas another study reported no correlation between total plasma folate concentration and NK cell cytotoxicity in Italian elderly $^{70}$.

NK activity was followed in a trial with 60 healthy subjects aged over 70 years who received over 4 months in addition to the regular diet a special nutritional formula providing, among other nutrients, $400 \mu \mathrm{g}$ folic acid, $120 \mathrm{IU}$ vitamin $\mathrm{E}$ and $3.8 \mu \mathrm{g}$ vitamin $\mathrm{B}_{12}$. NK cell cytotoxicity increased in supplemented subjects and decreased in non-supplemented participants. Supplemented subjects reported less infections, suggesting that this nutritional supplement increased innate immunity and provided protection against infections in elderly people ${ }^{71}$.

\section{Vitamin $B_{12}$}

Vitamin $\mathrm{B}_{12}$ is involved in carbon-1 metabolism and there are interactions with folate metabolism. In a vitamin $\mathrm{B}_{12}$-deficient state the irreversible reaction that forms 5-methyl tetrahydrofolate (THF) results in an inactive form of folate if it is not de-methylated by methionine synthase. The "trapping" of 5-methyl THF may result in a secondary folate deficiency with impairments in thymidine and purine synthesis and subsequently in DNA and RNA synthesis, leading to alterations in immunoglobulin secretion ${ }^{72}$.

A human study in vitamin $B_{12}$ deficient patients evaluated the alterations of immunological indicators following administration of vitamin $\mathrm{B}_{12}$. In these patients, a significant decrease was found in the number of lymphocytes and $\mathrm{CD}^{+}$cells and in the proportion of $\mathrm{CD}^{+}$cells. In addition, findings showed an abnormally high $\mathrm{CD} 4^{+} / \mathrm{CD}^{+}$ratio, and suppressed $\mathrm{NK}$ cell activity. Supplementation with vitamin $\mathrm{B}_{12}$ reversed these effects indicating that it may act as a modulatory agent for cellular immunity, especially in relation to $\mathrm{CD} 8^{+}$ and $\mathrm{NK}$ cells ${ }^{73}$.

In elderly subjects (aged $>70$ years) who received over 4 months in addition to the regular diet a special nutritional formula providing, among other nutrients, $120 \mathrm{IU}$ vitamin $\mathrm{E}$, $3.8 \mu \mathrm{g}$ vitamin $\mathrm{B}_{12}$, and $400 \mu \mathrm{g}$ folic acid, NK cell cytotoxic activity increased in supplemented subjects, indicating 
increased innate immunity in elderly people ${ }^{71}$. Immunocompetent adults (aged $>65$ years) with low vitamin $B_{12}$ serum concentrations, had an impaired antibody response to pneumococcal polysaccharide vaccine ${ }^{74}$. These few studies demonstrate the importance of a sufficient vitamin $B_{12}$ status to maintain an adequate immune response, especially in the elderly who have a high percentage (up to $15 \%$ ) of low serum vitamin $\mathrm{B}_{12}$ concentrations ${ }^{75}$.

\section{Trace elements and immune function}

The role of trace elements is covered by other authors in this special issue and is only briefly sketched here.

\section{Selenium}

Selenium is essential for optimum immune response and influences the innate and acquired immune systems. It plays a key role in the redox regulation and antioxidant function through glutathione peroxidases that remove excess of potentially damaging radicals produced during oxidative stress. Thus, selenium plays an important role in balancing the redox state, and helping to protect the host from oxidative stress generated by the microbicidal effects of macrophages and during inflammatory reactions. The selenoenzyme thioredoxin reductase affects the redox regulation of several key enzymes, transcription factors and receptors, including ribonucleotide reductase, glucocorticoid receptors, anti-inflammatory protein AP-1, and nuclear factor-kappa B (NFкB), which binds to DNA and activates expression of genes encoding proteins involved in immune response (cytokines, adhesion molecules). Selenium deficiency decreases immunoglobulin titres and aspects of cell-mediated immunity. Selenium supplementation can counteract these effects ${ }^{4,76-79}$.

\section{Zinc}

The immune related functions of zinc have been reviewed in the last few years ${ }^{50,80-82}$. Zinc is essential for highly proliferating cells, especially in the immune system and influences both innate and acquired immune functions. It is involved in the cytosolic defence against oxidative stress (superoxide dismutase activity) and is an essential cofactor for thymulin which modulates cytokine release and induces proliferation. Adequate zinc intake supports a Th1 response, and helps to maintain skin and mucosal membrane integrity and unbound zinc ions exert a direct antiviral effect on rhinovirus replication. Zinc supplementation increases cellular components of innate immunity (e.g. phagocytosis by macrophages and neutrophils, NK cell activity, generation of oxidative burst, DTH activity), antibody responses, and the numbers of cytotoxic $\mathrm{CD}^{+} \mathrm{T}$ cells (Th1 response).

\section{Copper}

Copper has been shown to have a role in the development and maintenance of the immune system and a large number of experimental studies have demonstrated that copper status alters several aspects of neutrophils, monocytes and superoxide dismutase. Working together with catalase and glutathione peroxidase in the cytosolic antioxidant defence against ROS, copper is essential in the dismutation of superoxide anion to oxygen and $\mathrm{H}_{2} \mathrm{O}_{2}$, and diminishes damage to lipids, proteins, and DNA. Both copper deficiency and high intakes over longer periods can modulate several aspects of the immune response ${ }^{79,83-87}$.

Iron

The immune related functions of iron have been subject to several reviews since $2001^{88-91}$. Iron is essential for electron transfer reactions, gene regulation, binding and transport of oxygen, and regulation of cell differentiation and cell growth. Iron is a critical component of peroxide and nitrous oxide generating enzymes. It is involved in the regulation of cytokine production and mechanism of action, and in the activation of protein kinase $\mathrm{C}$, which is essential for phosphorylation of factors regulating cell proliferation. In addition, iron is necessary for myeloperoxidase activity which is involved in the killing process of bacteria by neutrophils through the formation of highly toxic hydroxyl radicals. Therefore, any alteration in cellular iron homeostasis to either deficiency or overload has unfavourable functional consequences on the immune system. Since pathogens such as infectious microorganisms and viruses require iron and other micronutrients for replication and survival as well, it seems essential to restrict access of the infecting microorganism to iron, but to maintain a suitable concentration of iron that the host can mount an optimum immune response and avoid the possibility of excess amounts of iron which may induce free radical mediated damage ${ }^{91}$.

\section{Conclusions}

Inadequate intake and status of vitamins and trace elements may lead to suppressed immunity, which predisposes to infections and aggravates undernutrition. Evidence has accumulated that in humans certain nutrients selectively influence the immune response, induce dysregulation of a coordinated host response to infections in cases of deficiency and oversupply, and that deficiency may impact virulence of otherwise harmless pathogens. Thus, micronutrients are required at appropriate intakes for the immune system to function optimally. Available data indicate a role of vitamins $(A, D, E$, $\mathrm{B}_{6}, \mathrm{~B}_{12}$, folate, and $\mathrm{C}$ ), and trace elements (selenium, zinc, copper, and iron) on the immune response. They contribute to the body's natural defences on three levels by supporting physical barriers (skin/mucosa), cellular immunity and antibody production. Vitamins $\mathrm{A}, \mathrm{C}, \mathrm{E}$ and the trace element zinc assist in enhancing the skin barrier function. The vitamins $\mathrm{A}, \mathrm{B}_{6}, \mathrm{~B}_{12}, \mathrm{C}, \mathrm{D}, \mathrm{E}$ and folic acid and the trace elements iron, zinc, copper and selenium work in synergy to support the protective activities of the immune cells. Finally, all these micronutrients, with the exception of vitamin $\mathrm{C}$ and iron, are essential for antibody production. Vitamin $\mathrm{B}_{6}$, selenium, copper and zinc have a direct impact on antibody production or B-cell proliferation, vitamins $\mathrm{A}, \mathrm{D}$ and $\mathrm{E}$ stimulate Th2 response which in turn promotes humoral immunity, and the remaining micronutrients act indirectly by their roles in protein synthesis / cell growth. Overall, inadequate intake and status of these vitamins and trace elements may lead to 
suppressed immunity, which predisposes to infections and aggravates malnutrition. Therefore, supplementation with these selected micronutrients can support the body's natural defence system by enhancing all three levels of immunity.

\section{Conflict of interest statement}

SB, SM and ESW are employees of Bayer Health Care, a manufacturer of multivitamins. DHH is a consultant for Bayer Consumer Care. SM, ESW, SB and DHH co-wrote the manuscript.

\section{References}

1. Parkin J \& Cohen B (2001) An overview on the immune system. Lancet 357, 1777-1789.

2. Mackay I \& Rosen FS (2000) The immune system. Part I. $N$ Engl J Med 343, 37-49.

3. Mackay I \& Rosen FS (2000) The immune system. Part II. $N$ Engl J Med 343, 108-117.

4. Wintergerst ES, Maggini S \& Hornig DH (2007) Contribution of selected vitamins and trace elements to immune function. Ann Nutr Met 51, 301-323.

5. Calder PC \& Kew S (2002) The immune system: a target for functional foods? Br J Nutr 88, Suppl. 2, S165-S177.

6. Scrimshaw NS, Taylor CE \& Gordon JE (1968) Effects of infections on nutritional status. In Interactions of Nutrition and Infection, pp. 44-46. Geneva: World Health Organization, Monograph Series 57.

7. Calder PC \& Jackson AA (2000) Under-nutrition, infection and immune function. Nutr Res Rev 13, 3-29.

8. Stephensen CB (2001) Vitamin A, infection, and immunity. Annu Rev Nutr 21, 167-192.

9. Villamor E \& Fawzi WW (2005) Effects of vitamin A supplementation on immune responses and correlation with nutritional outcome. Clin Microbiol Rev 18, 446-464.

10. Sommer A, Katz J \& Tarwotjo I (1984) Increased risk of respiratory disease and diarrhea in children with preexisting mild vitamin A deficiency. Am J Clin Nutr 40, 1090-1095.

11. Barreto ML, Santos LMP, Assis AMO, Araujo MP, Farenzena GG, Santos PA \& Fiaccone RL (1994) Effect of vitamin A supplementation on diarrhoea and acute lower-respiratory tract infections in young children in Brazil. Lancet 344, 228-231.

12. Beaton GH, Martorell R, Aronson KJ, Edmonston B, McCabe G, Ross AC \& Harvey B (1993) Effectiveness of vitamin A supplementation in the control of young child morbidity and mortality in developing countries. Geneva: Subcommittee on Nutrition, Administrative Committee on Coordination; World Health Organization; State of the Art Discussion Paper No 13.

13. The Vitamin A and Pneunomia Working Group (1995) Potential interventions for the prevention on childhood pneumonia in developing countries: a meta-analysis of data from field trials to assess the impact of vitamin A supplementation on pneumonia morbidity and mortality. Bull WHO 73, 609-619.

14. Semba RD (2004) Vitamin A. In Diet and Human Immune Function, chapter 6, pp. 105-131 [DA Hughes, LG Darlington and A Bendich, editors]. Totowa, NJ: Humana Press.

15. Ramakrishnan U, Web AL \& Ologoudou K (2004) Infection, immunity, and vitamins. In Handbook of Nutrition and Immunity, pp. 93-115 [NE Gershwin, P Nestel and CL Keen, editors]. Totoja, NJ: Humana Press.

16. Dawson HD, Li NQ, Deciccio KL, Nibert JA \& Ross AC (1999) Chronic marginal vitamin A status reduces natural killer cell number and activity and function in aging Lewis rats. $J$ Nutr 129, 1510-1517.

17. Aukrust P, Mueller F, Ueland T, Svardal A, Berge R \& Froland SS (2000) Decreased vitamin A levels in common variable immunodeficiency: vitamin A supplementation in vivo enhances immunoglobulin production and downregulates inflammatory responses. Eur J Clin Invest 30, 252-259.

18. Halevy O, Arazi Y, Melamed D, Friedman A \& Sklan D (1994) Retinoic acid receptor-alpha gene expression is modulated by dietary vitamin $\mathrm{A}$ and by retinoic acid in chicken $\mathrm{T}$ lymphocytes. J Nutr 124, 2139-2146.

19. Cantorna MT, Nashold FE \& Hayes C (1994) In vitamin A deficiency multiple mechanism establish a regulatory $\mathrm{T}$ helper cell imbalance with excess Th1 and insufficient Th2 function. J Immunol 152, 1515-1522.

20. Long KZ \& Santos JL (1999) Vitamins and the regulation of the immune response. Ped Inf Dis J 18, 283-290.

21. Rahman MM, Mahalanabis D, Alvarez JO, Wahed MA, Islam MA \& Habte D (1997) Effect of early vitamin A supplementation on cell-mediated immunity in infants younger than 6 months. Am J Clin Nutr 65, 144-148.

22. Semba RD (1999) Vitamin A as "anti-infective" therapy. J Nutr 129, 783-791.

23. Semba RD (2002) Vitamin A, infection and immune function. In Nutrition and Immune Function (Frontiers in Nutritional Science, No. 1) chapter 8, pp. 151-170 [PC Calder, CJ Field and HS Gill, editors]. Oxford: CABI Publishing.

24. Hayes CE, Nashold FE, Spach KM \& Pedersen LB (2003) The immunological functions of the vitamin $\mathrm{D}$ endocrine system. Cell Molec Biol 49, 277-300.

25. Griffin MD, Xing N \& Kumar R (2003) Vitamin D and its ana$\operatorname{logs}$ as regulators of immune activities and antigen presentation. Annu Rev Nutr 23, 117-145.

26. Cantorna MT, Zhu Y, Froicu M \& Wittke A (2004) Vitamin D status, 1,25-dihydroxy- vitamin $\mathrm{D}_{3}$, and the immune system. $A m$ $J$ Clin Nutr 80, 1717S-1720S.

27. Veldman CM, Cantorna MT \& DeLuca HF (2000) Expression of 1,25-dihydroxyvitamin $\mathrm{D}_{3}$ receptor in the immune system. Arch Biochem Biophys 374, 334-338.

28. DeLuca HF \& Cantorna MT (2001) Vitamin D: its role and uses in immunology. FASEB $J \mathbf{1 5}, 2579-2585$.

29. Lemire JM, Archer DC, Beck L \& Spiegelberg HL (1995) Immunosuppressive actions of 1,25(OH)2D3: preferential inhibition of Th1 functions. J Nutr 125, 1704S-1708S.

30. Hypponen E, Laara E, Reunanen A, Jarvelin MR \& Virtanen SM (2001) Intake of vitamin D and risk of type 1 diabetes: a birth-cohort study. Lancet 358, 1500-1503.

31. The EURODIAB substudy 2 study group (1999) Vitamin D supplement in early childhood and risk for type I (insulindependent) diabetes mellitus. Diabetologia 42, 51-54.

32. Cannell JJ, Vieth R, Umhau JC, Holick MF, Grant WB, Madronich S, Garland CF \& Giovannucci E (2006) Epidemic influenza and vitamin D. Epidemiol Infec 134, 1129-1140.

33. Meydani SN, Han SN \& Wu D (2005) Vitamin E and immune response in the aged: molecular mechanism and clinical implications. Immunol Rev 205, 269-284.

34. Castle S (2000) Clinical relevance of age-related immune dysfunction. Clin Inf Dis 31, 578-585.

35. Burns EA \& Goodwin JS (2004) Effect of aging on immune function. $J$ Nutr Health Aging 8, 9-18.

36. Miller RA (1996) The aging immune system: primer and prospectus. Science 273, 70-74.

37. Meydani SN, Meydani M, Blumberg JB, Leka LS, Siber G, Loszewski R, Thompson C, Pedrosa MC, Diamond RD \& Stollar BD (1997) Vitamin E supplementation and in vivo immune response in healthy elderly subjects. A randomized controlled trial. J Am Med Assoc 277, 1380-1386. 
38. Meydani SN, Barklund MP, Liu S, Miller RA, Cannon JG, Morow FD, Rocklin R \& Blumberg JB (1990) Vitamin E supplementation enhances cell-mediated immunity in healthy elderly subjects. Am J Clin Nutr 53, 557-563.

39. Pallast E, Schouten E, de Waart F, Fonk H, Doekes G, von Blomberg B \& Kok FJ (1999) Effect of 50- and 100-mg vitamin E supplements on cellular immune function in non-institutionalized elderly persons. Am J Clin Nutr 69, 1273-1281.

40. Meydani SN, Leka LS, Fine BC, Dallal GE, Keusch GT, Singh MF \& Hamer DH (2004) Vitamin E and respiratory tract infections in elderly nursing home residents: a randomized controlled trial. $J$ Am Med Assoc 292, 828-836.

41. Graat JM, Schouten EG \& Kok FJ (2002) Effect of daily vitamin $\mathrm{E}$ and multivitamin/multimineral supplementation on acute respiratory tract infections in elderly persons. $J$ Am Med Assoc 288, 715-721.

42. De la Fuente M, Ferrandez MD, Burgos MS, Soler A, Prieto A \& Miquel J (1998) Immune function in aged women is improved by ingestion of vitamins C and E. Can J Physiol Pharmacol 76, 373-380.

43. Park OJ, Kim HYP, Kim WK, Kim YJ \& Kim SH (2003) Effect of vitamin $\mathrm{E}$ supplementation on antioxidant defense systems and humoral immune response in young, middle-aged and elderly Korean women. J Nutr Sci Vitaminol 49, 94-99.

44. DeWaart FG, Portengen L, Doekes G, Verwaal CJ \& Kok FJ (1997) Effect of 3 months vitamin E supplementation on indices of the cellular and humoral immune response in elderly subjects. Br J Nutr 78, 761-774.

45. Hara M, Tanaka K \& Hirota Y (2005) Immune response to influenza vaccine in healthy adults and the elderly: association with nutritional status. Vaccine 23, 1457-1463.

46. Lee CYJ \& Wan JMF (2000) Vitamin E supplementation improves cell-mediated immunity and oxidative stress of Asian men and women. J Nutr 130, 2932-2937.

47. Han SN, Adolfsson O, Lee CK, Prolla TA, Ordovas J \& Meydani SN (2004) Vitamin E and gene expression in immune cells. Ann NY Acad Sci 1031, 96-101.

48. Hughes DA (2000) Antioxidant vitamins and immune function. In Nutrition and Immune Function, pp. 171-191 [PC Calder, CJ Field and HS Gill, editors]. Wallingford: CAB International.

49. Ames BN, Shigenaga MK \& Hagen TM (1993) Oxidants, antioxidants, and the degenerative disease of aging. Proc Natl Acad Sci USA 90, 7915-7922.

50. Wintergerst ES, Maggini S \& Hornig DH (2006) Immuneenhancing role of vitamin $\mathrm{C}$ and zinc and effect on clinical conditions. Ann Nutr Met 50, 85-94.

51. Anderson R, Oosthuizen R, Maritz R, Theron A \& Van Rensburg AJ (1980) The effects of increasing weekly doses of ascorbate on certain cellular and humoral immune functions in normal volunteers. Am J Clin Nutr 33, 71-76.

52. Jeng KC, Yang CS, Siu WY, Tsai YS, Liao WJ \& Kuo JS (1996) Supplementation with vitamin C and E enhances cytokine production by peripheral blood mononuclear cells in healthy adults. Am J Clin Nutr 64, 960-965.

53. Haertel C, Strunk T, Bucsky P \& Schultz C (2004) Effects of vitamin $\mathrm{C}$ on intracytoplasmic cytokine production in human whole blood monocytes and lymphocytes. Cytokine 27, $101-106$.

54. Johnston CS (1991) Complement component C1q unaltered by ascorbate supplementation in healthy men and women. $J$ Nutr Biochem 2, 499-501.

55. Jacob RA, Kelley DS, Pianalto FS, Swendseid ME, Henning SM, Zhang JZ, Ames BN, Fraga CG \& Peters JH (1991) Immunocompetence and oxidant defense during ascorbate depletion of healthy men. Am J Clin Nutr 54, 1302S-1309S.
56. Panush RS, Delafuente JC, Katz P \& Johnson J (1982) Modulation of certain immunologic responses by vitamin C. III. Potentiation of in vitro and in vivo lymphocyte response. Int $J$ Vitam Nutr Res 23, 35-47.

57. Kennes B, Dumont I, Brohee D, Hubert C \& Neve P (1983) Effect of vitamin $\mathrm{C}$ supplements on cell-mediated immunity in older people. Gerontology 29, 305-310.

58. Hume R \& Weyers E (1973) Changes in leukocyte ascorbic acid during the common cold. Scot Med J 18, 3-7.

59. Douglas RM, Hemilä H, Chalker E \& Treacy B (2007) Vitamin C for preventing and treating the common cold. In Cochrane Database of Systematic Reviews, Issue 3. Art. No.: CD000980. DOI: 10.1002/14651858.CD000980.pub3.

60. Institute of Medicine (1998) Dietary reference intakes for thiamin, riboflavin, niacin, vitamin $\mathrm{B}_{6}$, folate, vitamin $\mathrm{B}_{12}$, pantothenic acid, biotin, and choline. Washington, D.C.: Food and Nutrition Board, Institute of Medicine, National Academy Press, chapter 7: Vitamin $\mathrm{B}_{6}$, pp. 150-195.

61. Leklem JE (2001) Vitamin $\mathrm{B}_{6}$. In Handbook of Vitamins, 3rd ed, revised and expanded. chapter 10, pp. 339-396 [RB Rucker, JW Suttie, DB McCormick and LJ Machlin, editors]. New York: Marcel Dekker Inc.

62. Chandra RK \& Sudhakaran L (1990) Regulation of immune responses by vitamin $\mathrm{B}_{6}$. Ann NY Acad Sci 585, 404-423.

63. Rall LC \& Meydani SN (1993) Vitamin $B_{6}$ and immune competence. Nutr Rev 51, 217-225.

64. Trakatellis A, Dimitriadou A \& Trakatelli M (1997) Pyridoxine deficiency: new approaches in immunosuppression and chemotherapy. Postgr Med J 73, 617-622.

65. Ockhuizen T, Spanhaak S, Mares N, Veenstra J, Wedel M, Mulder J \& van den Berg H (1990) Short-term effects of marginal vitamin $\mathrm{B}$ deficiencies on immune parameters in healthy young volunteers. Nutr Res 10, 483-492.

66. Miller LT \& Kerkvliet NT (1990) Effect of vitamin $\mathrm{B}_{6}$ on immune competence in the elderly. Ann NY Acad Sci 587, $49-54$.

67. Dhur A, Galan P \& Hercberg S (1991) Folate status and the immune system. Progr Food Nutr Sci 15, 43-60.

68. Courtemanche C, Elson-Schwab I, Mashiyuama ST, Kerry N \& Ames BN (2004) Folate deficiency inhibits the proliferation of primary human $\mathrm{CD}^{+} \mathrm{T}$ lymphocytes in vitro. J Immunol 173, 3186-3189.

69. Troen AM, Mitchell B, Sorensen B, Wener MH, Johnston A, Wood B, Selhub J, McTiernan A, Yasui Y, Oral E, Potter JD \& Ulrich CM (2006) Unmetabolized folic acid in plasma is associated with reduced natural killer cell cytotoxicity among postmenopausal women. J Nutr 136, 189-194.

70. Ravaglia G, Forti P, Maioli F, Bastagli L, Facchini A, Mariani E, Savarino L, Sassi S, Cucinotta D \& Lenaz G (2000) Effect of micronutrient status on natural killer cell immune function in healthy free-living subjects aged $\geqq 90$ years. Am J Clin Nutr 71, 590-598.

71. Bunout D, Barrera G, Hirsch S, Gattas V, de la Maza MP, Haschke F, Steenhout P, Klassen P, Hager C, Avendano M, Petermann M \& Munoz C (2004) Effects of a nutritional supplement on the immune response and cytokine production in free-living Chilean elderly. J Parenteral Enteral Nutr 28, 348-354.

72. Bailey LB \& Gregory JF III (2006) Folate. In Present Knowledge in Nutrition, 9th ed., chapter 22, pp. 278-301 [BA Bowman and RM Russel, editors]. Washington, DC: ILSI Press.

73. Tamura J, Kubota K, Murakami H, Sawamura M, Matsushima T, Tamura T, Saitoh T, Kurabayashi H \& Naruse T (1999) Immunomodulation by vitamin B12: augmentation of $\mathrm{CD} 8+\mathrm{T}$ lymphocytes and natural killer $(\mathrm{NK})$ cell activity in vitamin $\mathrm{B}_{12}$-deficient patients by methyl- $\mathrm{B}_{12}$ treatment. Clin Exp Immunol 116, 28-32. 
74. Fata FT, Herzlich B, Schiffman G \& Ast AL (1996) Impaired antibody responses to pneumococcal polysaccharide in elderly patients with low serum vitamin $\mathrm{B}_{12}$ levels. Ann Intern Med 124, 299-304.

75. Stabler SP, Lindenbaum J \& Allen RH (1997) Vitamin $B_{12}$ deficiency in the elderly: current dilemmas. Am J Clin Nutr 66, 741-749.

76. Arthur JR, McKenzie R \& Beckett GJ (2003) Selenium in the immune system. J Nutr 133, 1457S-1459S.

77. Ferencik M \& Ebringer L (2003) Modulatory effects of selenium and zinc on the immune system. Folia Microbiol 48, 417-426.

78. Ryan-Harshman M \& Aldoori W (2005) The relevance of selenium to immunity, cancer, and infectious/inflammatory diseases. Can J Diet Prac Res 66, 98-102.

79. Klotz LO, Kroencke KD, Buchczyk DP \& Sies H (2003) Role of copper, zinc, selenium, and tellurium in the cellular defense against oxidative and nitrosative stress. J Nutr 133, 1448S-1451S.

80. Prasad AS (2000) Effects of zinc deficiency on immune functions. J Trace Elem Exp Med 13, 1-30.

81. Ibs KH \& Rink L (2003) Zinc-altered immune function. $J$ Nutr 133, 1452S-1456S.

82. Fraker PJ \& King LE (2004) Reprogramming of the immune system during zinc deficiency. Ann Rev Nutr 24, 277-298.
83. Percival SS (1988) Copper and immunity. Am J Clin Nutr 67, 1064S-1085S.

84. Bonham M, O'Connor JM, Hannigan BM \& Strain JJ (2002) The immune system as a physiological indicator of marginal copper status? Br J Nutr 87, 393-403.

85. Minatel L \& Carfagnini JC (2000) Copper deficiency and immune response in ruminants. Nutr Res 2010, 1519-1529.

86. Linder MC \& Hazegh-Azam M (1996) Copper biochemistry and molecular biology. Am J Clin Nutr 63, 797S-811S.

87. Pan YJ \& Loo G (2000) Effect of copper deficiency on oxidative DNA damage in Jurkat T-lymphocytes. Free Rad Biol Med 28, 824-830.

88. Weiss G (2004) Iron. In Diet and Human Immune Function, chapter 11, pp. 203-215 [DA Hughes, LG Darlington and A Bendich, editors]. Totowa, NJ: Humana Press.

89. Schaible UE \& Kaufmann SHE (2004) Iron and microbial infection. Nature Rev Microbiology 2, 946-953.

90. Weiss G (2002) Iron and immunity: a double-edged sword. Eur J Clin Invest 32, Suppl 1, 70-78.

91. Oppenheimer SJ (2001) Iron and its relation to immunity and infectious disease. J Nutr 131, 616S-635S. 